\author{
脂質過酸化と妊娠中毒症（第 2 報） \\ 一胎盤絨毛上皮刷子縁膜の D-グルコース輸送能に及ぼす \\ 細胞膜脂質過酸化の影響一 \\ 奈良県立医科大学産科婦人科学教室 \\ 阪 本 義 晴
}

\title{
Lipid peroxidation and preeclampsia (Part 2)
}

- The influence of lipid peroxidation in the cell membrane on the D-glucose

transport activity of human placental syncytiotrophoblast -

Yoshiharu SAKAMOTO

Department of Obstetrics and Gynecology, Nara Medical University, Nara, Japan

The influence of lipid peroxidation in the cell membrane of human placental syncytiotrophoblast (placental brush border membrane; PBBM) on the impairment of placental transport in preeclampsia was studied.

Lipid peroxides in the placental brush border membrane (PBBM) were measured by TBA method, and the D-glucose transport activity and glucose transporter 1 (GLUT1) expression of PBBM were analyzed using the rapid filtration technique and Western blotting densitometry, respectively. Lipid peroxide concentrations in the PBBM were increased significantly in preeclampsia $(\mathrm{p}<0.01)$. Significant reduction of the D-glucose transport activity without the decrese of GLUT1 expression of PBBM was observed in preeclampsia $(\mathrm{p}<0.001)$.

The influence of artificial peroxidation of PBBM by tertiary-butylhydroperoxide ( $t$-BHP) and the effects of vitamin $\mathrm{E}$ on this peroxidation were also investigated by measuring the D-glucose transport activity in vitro. Significant reduction of D-glucose transport activity was observed in the artificially peroxidated PBBM $(\mathrm{p}<0.001)$. The peroxidation activity of t-BHP was prevented by the addition of vitamin $\mathrm{E}$, and at the same time, reduction of D-glucose transport activity of PBBM caused by t-BHP was able to be prevented depending on the concentration $(20 \sim 40 \mu \mathrm{g} / \mathrm{ml} ; \mathrm{p}<0.005, \mathrm{p}<0.001)$.

These results suggest that in preeclampsia, the lipid peroxidation of PBBM plays an important role in the impaired placental glucose transport activity and vitamin E promotes the D-glucose transport by preventing the lipid peroxidation of PBBM.

Keywords: lipid peroxidation, preeclampsia, glucose transport, placental brush border membrane, vitamin $\mathrm{E}$

緒言

脂質は細胞膜の重要な構成成分であるために，その恒常性が少しでも障害されるとたちまち正常な 細胞機能が保たれなくなる。著者は, 妊娠中毒症胎盤においては, 種々の酸化的ストレスや血漿中ビ タミン $\mathrm{E}$ 濃度の低下によって増加した絨毛上皮刷子縁膜内の過酸化脂質が絨毛上皮刷子縁膜の持つ 
ADP 分解活性を低下させる結果, 血小板凝集阻止活性が低下し, 胎盤微小循環維持機能が障害され ていることをすで報告した1)。

胎盤に拉ける重要な生物作用の一つに母体から胎児へのグルコース輸送があげられるが，䋐毛上皮 刷子縁膜における細胞膜構成成分の变化はその機能に大さな影響を与えるものと推察される。そこ で，妊娠中毒症胎艋に拈ける䋐毛上皮刷子縁膜の脂質過酸化とグルコース輸送能につき検討した。

\section{研究方法}

\section{1. 研究対象と試料の採取}

妊娠末期の正常妊婦20例（36.1 \pm 1.9 週, $\mathrm{M} \pm \mathrm{SD}$ ) と重症妊娠中毒症妊婦13例（35.3 \pm 1.3 週， $\mathrm{M} \pm \mathrm{SD}$ ）を対象とし，分婏直後の胎盤を用いて Smith らの方法2) 飞準じて䋐毛上皮刷子縁膜小胞を 分離した1)3)。また，胎盤の一部はホルマリンで固定した後パラフィン包埋した。

なお, 妊娠中毒症については日本産科婦人科学会の妊娠中毒症判定基準に従って分類し（重症例の 英文名は preeclampsia と表現した)，また胎盤については妊婦の同意を得て実験に使用した。

\section{2. 試料中の過酸化脂質量とビタミン $E$ ( $\alpha$-tocopherol) 濃度の測定}

試料中の過酸化脂質量は TBA 法により測定した ${ }^{1)}$ 。なお，胎盤䋐毛上皮刷子縁膜については，5 $\mathrm{mg} / \mathrm{ml}$ 飞調整したのち前述の方法で過酸化脂質量を測定し, 蛋白量で除することにより $\mathrm{nmol}$ $\mathrm{MDA} / \mathrm{mg}$ protein として表現した1)。

\section{3. 胎盤における GLUT1 の発現に関する検討}

パラフィン包埋した正常妊娠 3 例および重症妊娠中毒症 3 例の胎盤組織を用いて $3 \mu \mathrm{m}$ の切片を作 成し，GLUT1 に対する免疫蛍光染色を既報の方法4)で施行し，GLUT1 の発現を検討した。抗 GLUT1 抗体はCHEMICON 社製を用いた。

\section{4. 胎盤絨毛上皮刷子緑膜における D-グルコース輸送能に関する検討}

正常妊娠10例ならびに重症妊娠中毒症群 8 例の胎盤を用いて絨毛上皮刷子縁膜におケる D-グル コース輸送能を膜急速ろ過法で検討した5)。すなわち, 反応溶液である $10 \mathrm{mM}$ Hepes-Tris buffer (pH 7.4, $0.25 \mathrm{M}$ mannitol・0.1 M NaCl・5 mM の D-グルコースを含む) に刷子縁膜小胞を加えること によって反応を開始し， 20 秒後に $4^{\circ} \mathrm{C}$ の buffer にて反応を停止してミリポアフィルター（HA 0.45 $\mu \mathrm{m})$ を用いて急速膜ろ過を行った。ついで膜フィルターを $3 \mathrm{ml}$ の toluene scintillator 液に入れて放射 活性を測定し, 刷子縁膜小胞の蛋白量で除した值を刷子縁膜の D-グルコース輸送能 $(\mathrm{nmol} / \mathrm{mg}$ protein $/ 20 \mathrm{sec}$ ）とした。これは20秒間に膜小胞内に取り込まれる D-グルコース量に相当し, 同種の膜小 胞を用いた輸送実験に適した方法で，再現性も我々の検討で約 $3 \%$ 以内であった。

\section{5. 胎盤絨毛上皮刷子緑膜における GLUT1 蛋白量の定量}

正常妊娠 5 例ならびに重症妊娠中毒症群 5 例の胎盤の絨毛上皮刷子縁膜を SDS で可溶化した後, SDS-polyacrylamide gel で電気泳動を行った。これをニトロセルロース膜に転写した後, 抗 GLUT1 抗体による western blotting 法67) を施行し，50 kD に発現した GLUT1 蛋白をデンシトメーターにて 定量化した。なお，陽性コントロールとしては既に GLUT1 の発現が確認されている赤血球膜分画を 用い，陰性コントロールには胎盤での発現のない抗 GLUT4 抗体を用いた。

\section{6. 胎盤䄉毛上皮刷子緑膜小胞の脂質過酸化が D-グルコース輸送能に与える影響に関する検討}

正常胎盤 5 例の刷子縁膜小胞 $(1.0 \mathrm{mg} / \mathrm{ml})$ と tertiary-butylhydroperoxide (t-BHP; 最終濃度 100 $\mu \mathrm{M})$ を $37^{\circ} \mathrm{C} ， 30$ 分間 incubation することにより脂質の過酸化を行った。過酸化処理した刷子縁膜小 
胞は, $0.25 \mathrm{M}$ mannitol 添加 $10 \mathrm{mM}$ Hepes-Tris buffer (pH 7.4)により 3 回洗浄と遠心を繰り返した。 処理前後の胎盤䋐毛上皮刷子縁膜小胞を buffer 飞懸濁 $(5 \mathrm{mg} / \mathrm{mg}) し て$, 過酸化脂質量および D-グル コース輸送能を測定した。

7. 胎盤絨毛上皮刷子縁膜の脂質過酸化とD-グルコース輸送能に与えるビタミン $E$ の影響に関する検 討

前述の方法で刷子縁膜小胞を $100 \mu \mathrm{M}$ の $\mathrm{t}$-BHP 飞て処理する際に, ビタミン $\mathrm{E}$ ( $\alpha$-tocopherol) 0 40 $\mu \mathrm{g} / \mathrm{ml}$ を最終濃度 $0.1 \%$ 以下のエタノールをキャリアーとして同時添加し, 刷子縁膜の過酸化 脂質量拉よび D-グルュース輸送能を測定した。

\section{8. 統計学的解析}

得られた測定值についてはすべて $M \pm S$ S.D. で表し, student’s t 検定により統計学的有意差を判定 した。

\section{研 究 成 績}

\section{1. 正常末期胎盤における GLUT1 の発現に関する検討}

GLUT1 は, 正常妊娠胎盤と重症妊娠中毒症胎盤の䋐毛上皮に広く発現して扮り, 刷子縁膜側にも 豊富に発現していた（Fig. 1)。

2. 胎盤絨毛上皮刷子緑膜における D-グルコース輸送能に関する検討 胎盤絨毛上皮刷子縁膜におケる D-グルコース輸送能 $(\mathrm{nmol} / \mathrm{mg}$ protein $/ 20 \mathrm{sec})$ は, 重症妊娠中毒

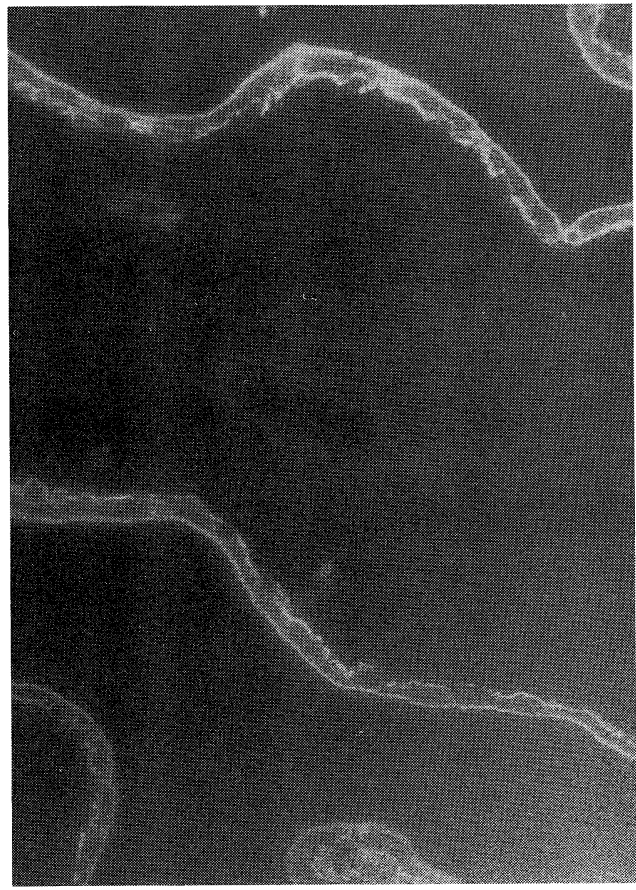

normal preg.

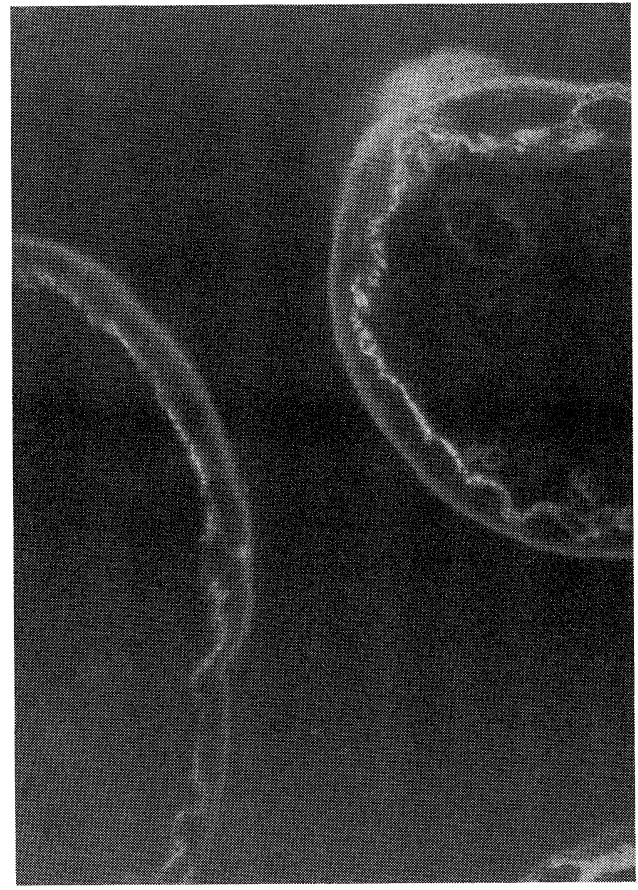

preeclampsia

Fig. 1 GLUT1 expression in placental brush border membrane (PBBM) (imunofluorescent stain) 
症群 $(16.5 \pm 4.3)$ で正常妊娠群 $(22.0 \pm 4.0)$ 飞比し有意に低值であった $(\mathrm{p}<0.001)$ (Fig. 2)。

\section{3. 胎盤緁毛上皮刷子縁膜における GLUT1 蛋白量に関する検討}

䋐毛上皮刷子縁膜に抢ける GLUT1 蛋白量 (正常妊娠群の平均を 1.0 とした arbitrary unit) は, 重 症妊娠中毒症群 $(1.06 \pm 0.21)$ と正常妊娠群 $(1.0 \pm 0.15)$ との間に有意差を認めなかった (Fig. 3)。

\section{4. 胎盤絨毛上皮刷子緑膜小胞の脂質過酸化が D-グルコース輸送能に与える影響に関する検討}

絨毛上皮刷子縁膜を $\mathrm{t}-\mathrm{BHP}$ で過酸化処理すると, 過酸化処理前の刷子縁膜小胞の D-グルコース輸 送能 $(\mathrm{nmol} / \mathrm{mg}$ protein $/ 20 \mathrm{sec})$ は $22.0 \pm 4.0$ であったが，過酸化処理後には $13.5 \pm 3.0$ と有意な低下 を認めた $(\mathrm{p}<0.001)$ (Table 1$)$ 。

5. 胎盤䋐毛上皮刷子縁膜の脂質過酸化とD-グルコース輸送能に与えるビタミン $E$ ( $\alpha$-tocopherol)

\section{の影響に関する検討}

t-BHP で過酸化処理した胎盤絨毛上皮刷子縁膜小胞の D-グルュース輸送能 (nmol/mg protein $120 \mathrm{sec})$ は $13.5 \pm 3.0$ であったが，t-BHP とビタミンE ( $\alpha$-tocopherol) $20 \mu \mathrm{g} / \mathrm{ml}$ あるいは $40 \mu \mathrm{g} / \mathrm{ml}$ 同時添加した場合の D-グルコース輸送能はそれぞれ $17.5 \pm 3.2,20.1 \pm 3.9$ といずれる有意に増加した $(\mathrm{p}<0.005$ 拈よび $\mathrm{p}<0.001)$ （Table 1)。な抗これらの変化は，キャリアーとして使用した最終濃度 $0.1 \%$ 以下のエタノール単独では全く認められなかった。

\section{考察}

胎盤は母児間の物質輸送，ガス交換等を担い，胎児の発育と成熟に重要な役割を果たすが，その直 後の接点となるのは胎盤絨毛である。つまり, 胎盤絨毛上皮刷子縁膜は母児間の物質輸送の場であ り，その障害は胎児胎盤系全体飞悪影響を及ぼす可能性がある。

生体内で利用可能なグルコースである D-グルコースは胎児のエネルギー源として重要であり, 母 体血中濃度が増加すると胎盤を通過して速やかに胎児に輸送される。この輸送機構は, エネルギーを

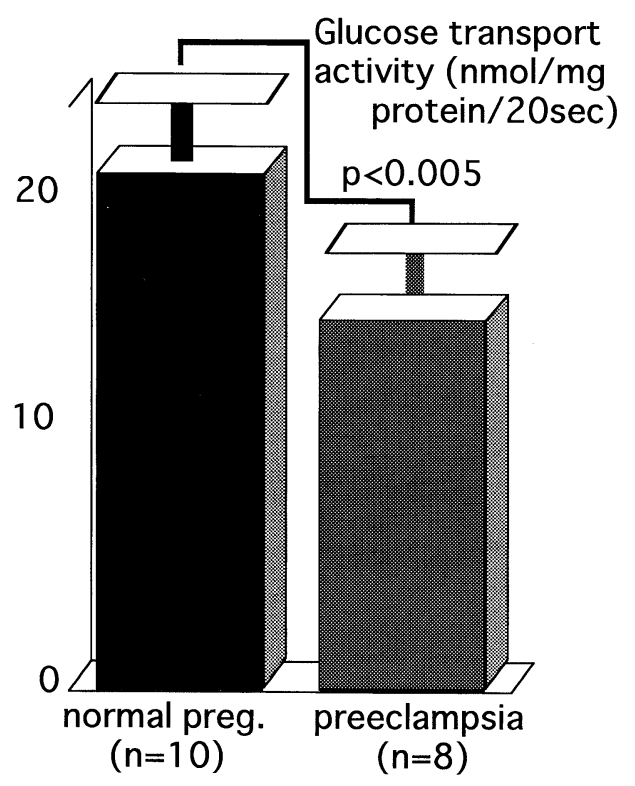

Fig. 2 Glucose transport activity of placental brush border membrane (PBBM) 


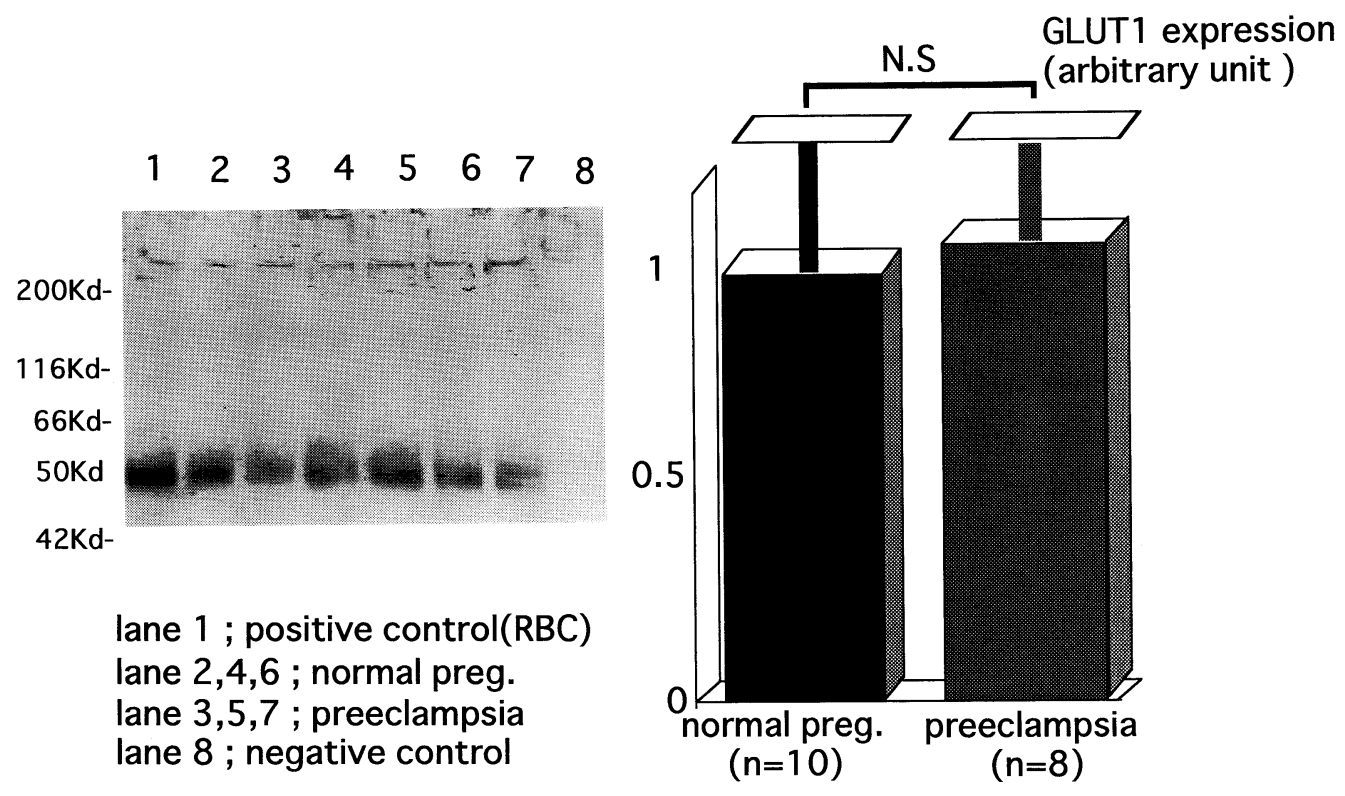

Fig. 3 GLUT1 expression in placental brush border membrane (PBBM) (western blotting densitometry)

Table 1 Effects of tertiary-butylhydroperoxide (t-BHP) and vitamin E ( $\alpha$-tocopherol) on lipid peroxidation and glucose transport activity of placental brush border membrane (PBBM) (mean \pm SD)

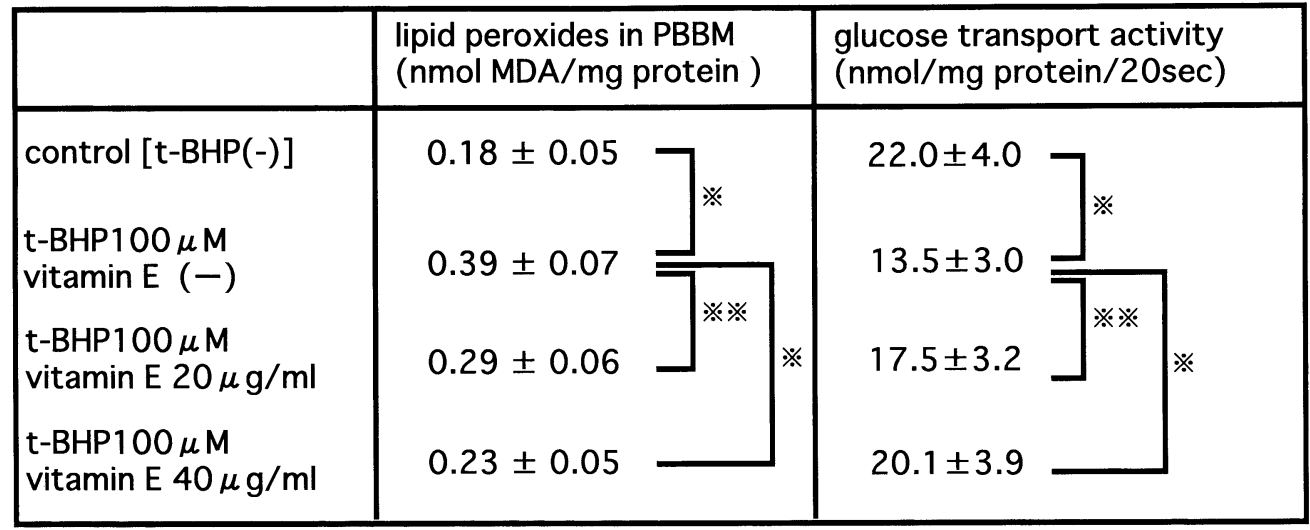

$($ mean $\pm \mathrm{SD}, \mathrm{n}=5)$

$$
\begin{aligned}
& ※ p<0.001 \\
& ※ \ldots<0.005
\end{aligned}
$$

必要としない促通拡散で，細胞膜上に存在する特異的な輸送担体である glucose transporter (GLUT) により媒介される。胎盤に执いては，1 型グルコーストランスポーター(GLUT1) の発現が知られて 抢り，胎盤の D-グルュース輸送は汪とんど GLUT1 を介するものと考光られている67)。GLUT1 は 膜貫通型の輸送担体で, D-グルコースの輸送は輸送担体自身の三次元構造が 2 種類の状態を交互に 繰り返すメカニズム (alternative conformation change) により成立するとされている899)。つまり，Dグルコースが GLUT1 の外側（もしくは内側）基質結合部位に結合する事によって輸送担体自身の三 
次元構造が変化し, 基質結合部位が外側から内側（もしくは内側から外側）に変化する事によりDグルユースの輸送が行われるのである。このメカニズムが維持されるためには, GLUT 周囲の細胞 膜の流動性がある程度確保されている必要があり, 膜脂質の過酸化により細胞膜の構造と機能が変化 すると膜の rigidity が増し, GLUT の機能に影響を与兄る可能性が考兄られる10)。

著者らは既報1) において妊娠中毒症胎盤の䋐毛上皮刷子縁膜内の過酸化脂質の増加していることを

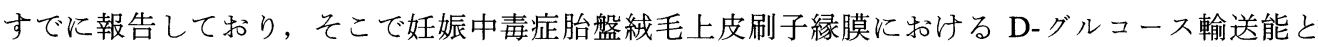
GLUT1 発現量の変化を検討した。

まず胎盤の䋐毛上皮刷子縁膜小胞を用いた in vitro 実験では, 重症妊娠中毒症胎盤の䋐毛上皮刷子 縁膜の D-グルコース輸送能は正常妊娠胎盤に比し有意に低下していることが判明した。ついで, 使 用した正常妊娠あるいは妊娠中毒症の胎盤絨毛上皮刷子縁膜に拈ける GLUT1 の局在を免疫組織学的 に検討したところ，いずれにおいても豊富に発現した GLUT1 を確認することができた。しかし，輸 送担体である GLUT1 の絨毛上皮刷子縁膜に抢ける発現量には両群の間で有意差を認めないことか ら, 細胞膜脂質の過酸化により GLUT1 機能が障害されている可能性が示唆された。GLUT1 は細胞 膜を12回貫通する膜貫通型の輸送担体であるが，D-グルュースが GLUT1 の外側（もしくは内側）基 質結合部位に結合する事によって輸送担体自身の三次元構造が変化し, 基質結合部位が外側から内側 （もしくは内側から外側）飞変化することによりD-グルコースの輸送が行われることが知られてい る。過酸化脂質は脂質の過酸化によって生ずるものであるが, 多価不飽和脂肪酸の過酸化は, その過 程で生じる hydroperoxide のために, 脂質過酸化が連鎖的に進むことが知られている。そのため生体 膜を構成する多価不飽和脂肪酸が過酸化を受けると, 連鎖的な膜脂質の過酸化が生じ, 膜の構造と機 能に影響を与えて臓器全体の病変に至ると考えられている。妊娠中毒症胎盤では絨毛上皮刷子縁膜に 括ける細胞膜脂質の過酸化が膜の流動性を変化させ, GLUT の機能の低下を介して胎盤絨毛上皮の 持つ物質輸送能に影響を与えていることが推察される。

そのため, この妊娠中毒症胎盤䋐毛上皮刷子縁膜に括けるD-グルコース輸送能の低下が刷子縁膜 の過酸化によって生じているのかを確認するために, 正常胎盤の絨毛上皮刷子縁膜小胞を tertiarybutylhydroperoxide (t-BHP) で過酸化する前後における D-グルユース輸送能の変化を in vitro 実験で 検討した。

その結果, t-BHP 処理により過酸化が生じた刷子縁膜では D-グルコース輸送能が著明に低下寸る ことが判明した。ビタミン $\mathrm{E}$ は脂溶性ビタミンとして膜周囲に存在し, 酸化脂質により惹起される 臍帯血管内皮細胞障害に対しても酸化連鎖抑制的に作用していること (Kaneko ら，1991) ${ }^{12)}$ が知ら れているので，さらにビタミン E の同時添加実験を行ったところ，ビタミン E はt t-BHP 処理による 胎盤絨毛上皮刷子縁膜の過酸化と D-グルコース輸送能の低下に対しても抑制的に作用することが明 らかとなった。つままり，ビタミン $\mathrm{E}$ は胎盤䋐毛上皮刷子縁膜の脂質過酸化を抑制することにより GLUT1 の機能を守り, D-グルコース輸送能の保持に働き, 胎盤絨毛上皮刷子縁膜局所に执いて重要 な役割を果たしていることが示唆された。

結 語

妊娠中毒症胎盤においては, 種々の酸化的ストレスや血漿中ビタミン $\mathrm{E}$ 濃度の低下によって, 䋐 毛上皮刷子縁膜内脂質の過酸化が進行して括り，この過酸化脂質が絨毛上皮刷子縁膜の GLUT1 の機 能を障害してグルコース輸送能が低下し，胎盤の物質輸送機能が障害されていることが推察された。 
今回明らかになった刷子縁膜の脂質過酸化による胎盤の物質輸送能の低下と第一報で示した微小循 環維持機能の低下1）を合わせて勘案すると，これらは妊娠中毒症における胎盤機能不全発症の重要な 病因のひとつと考えられるので, 酸化的ストレスと脂質過酸化の抑制が妊娠中毒症の予防と治療にき わめて有用であると考光られた。

\section{謝辞}

稿を終えるにめたり，ご指導，ご校閲を賜った恩師一條元彦名誉教授，森川 肇教授ならびに直接 のご指導を賜った飯岡秀晃元講師に深甚なる謝意を表するとともに, 森山郁子奈良県立医大看護短期 大学部教授をはじめ胎児胎盤研究グループの諸见に深謝いたします。

\section{文献}

1）阪本義晴: 脂質過酸化と妊娠中毒症（第 1 報）一胎盤絨毛上皮刷子縁膜の血小板凝集阻止活性に及注す脂質過酸化の 影響一. 日内分泌会誌, 1997; 73: 477-485

2) Smith, C.H., Nelson, D.M., King, B.F., Donohue, T.M., Ruzycki, S., Kelley, L.K.: Characterization of a microvillous membrane preparation from human placental syncythiotrophpblast; a morphologic biochemical, and physiologic study. Am. J. Obstet. Gynecol., 197; 128: 190-196

3）飯岡秀晃, 森山郁子, 尼崎真美, 伊藤公彦, 日野晃治, 一條元彦: Phosphate の胎盤輸送機構の解明（七ト胎盤䋐毛 膜（刷子縁膜）小胞を用いて)．日産婦誌，1985; 37: 2675-2680

4）山田嘉彦, 森山郁子, 飯岡秀晃, 赤田 忍, 橋本平嗣, 島本太香子, 阪本義晴, 一條元彦: ヒ上胎盤䋐毛上皮でのグ ルコース輸送動態. 日産婦誌, 1993; 45: 1137-1138

5) Lueke H.: Taurocholate-sodium co-transport by brush border membrane vesicles isolated from rat ileum. Biochem. J., 1978; 174: 951-958

6) Jansson, T., Wennergren, M., Illsley, N.P.: Glucose transporter protein expression in human placenta throughout gestation and in intrauterin growth retardation. J. Clin. Endocrinol. Metab., 1993; 77: 1554-1562

7) Sakata, M., Kurachi, H., Imai, T., Tadokoro, C., Yamaguchi, M., Yoshimoto, Y., Oka, Y., Miyake, A.: Increase in human placental glucose transporte-1 during pregnancy. Eur. J. Endoclinol., 1995; 132: 206-212

8) Barnet, J.E., Holman, G.D., Chalkley, R.A., Munday, K.A.: Evidence for two asymmetric conformational states in the human erythrocyte sugar-transport system. Biochem. J., 1975; 145: 417-429

9) Oka, Y., Asano, T., Shibasaki, Y., Lin, J.L., Tsukuda, K., Katagiri, H., Akanuma, Y., Takaku, F.: C-terminal glucose transporter is locked into a inward-facin from without transport activity. Nature, 1990; 345: 550-553

10) Jourd' Heuil, D., Paananen, P., Meddings, J.B.: Lipid peroxidation of the brush border membrane physical properties and glucose transport. Am. J. Physiol., 1993; 264: G1009-1015

11）八木国夫：過酸化脂質の病態生化学. 日本臨床, 1983; 41: 1920-1933

12) Kaneko, T., Nakano, S., Matsuo, M.: Protective effect of Vitamin E on linoletic acid hydroperoxide-induced injury to human endothelial cells. LIPIDS, 1991; 26: 345-348

（受付日 : '96, 11, 6)

（採択日：'96, 1, 8) 